Research Article

\title{
Tartrazine Removal from Aqueous Solution by HDTMA-Br-Modified Colombian Bentonite
}

\author{
Ronald A. Otavo-Loaiza $\mathbb{D}^{1},{ }^{1}$ Nancy R. Sanabria-González $(\mathbb{D})^{1}$ \\ and Gloria I. Giraldo-Gómez $\mathbb{( i D}^{2}$ \\ ${ }^{1}$ Departamento de Ingeniería Química, Facultad de Ingeniería y Arquitectura, \\ Universidad Nacional de Colombia Sede Manizales, Campus La Nubia, km 7 Vía al Aeropuerto, AA 127 Manizales, Colombia \\ ${ }^{2}$ Departamento de Física y Química, Facultad de Ciencias Exactas y Naturales, \\ Universidad Nacional de Colombia Sede Manizales, Campus La Nubia, km 7 Vía al Aeropuerto, AA 127 Manizales, Colombia
}

Correspondence should be addressed to Gloria I. Giraldo-Gómez; gigiraldogo@unal.edu.co

Received 6 May 2019; Revised 16 July 2019; Accepted 22 July 2019; Published 8 September 2019

Academic Editor: Rizwan Hasan Khan

Copyright (C) 2019 Ronald A. Otavo-Loaiza et al. This is an open access article distributed under the Creative Commons Attribution License, which permits unrestricted use, distribution, and reproduction in any medium, provided the original work is properly cited.

\begin{abstract}
The effect of $\mathrm{pH}$, ionic strength ( $\mathrm{NaCl}$ added), agitation speed, adsorbent mass, and contact time on the removal of tartrazine from an aqueous solution, using an organobentonite, has been studied. A complete factorial design $3^{2}$ with two replicates was used to evaluate the influence of the dye concentration $(30,40$, and $50 \mathrm{mg} / \mathrm{L})$ and amount of adsorbent $(25,35$, and $45 \mathrm{mg})$ on decolorization of the solution. Experimental data were evaluated with Design Expert ${ }^{\circledR}$ software using a response surface methodology (RSM) in order to obtain the interaction between the processed variables and the response. $\mathrm{pH}$ values between 2 and 9 , stirring speed above $200 \mathrm{rpm}$, and contact time of $60 \mathrm{~min}$ did not have a significant effect on decolorization. The optimum conditions for maximum removal of tartrazine from an aqueous solution of $30 \mathrm{mg} / \mathrm{L}$ were follows: $\mathrm{pH}=6.0, \mathrm{NaCl}$ concentration $=0.1 \mathrm{M}$, stirring speed $=230 \mathrm{rpm}$, temperature $=20^{\circ} \mathrm{C}$, contact time $=60 \mathrm{~min}$, and the organobentonite amount $=38.04 \mathrm{mg}$. The equilibrium isotherm at $20^{\circ} \mathrm{C}$ was analyzed by means of the Langmuir and Freundlich models, and the maximum adsorption capacity obtained was $40.79 \pm 0.71 \mathrm{mg} / \mathrm{g}$. This adsorption process was applied in a sample of industrial wastewater containing tartrazine and sunset yellow, having obtained a decolorization rate higher than $98 \%$ for both dyes. These results suggest that organobentonite is an effective adsorbent for the removal of anionic dyes from an aqueous solution.
\end{abstract}

\section{Introduction}

Organic pollutants commonly found in the aquatic environment are dyes, biocides compounds, phenols, surfactants, pesticides, and pharmaceuticals, among others $[1,2]$. As coloring agents, some dyes are resistant to degradation and their presence in water might be harmful to human beings and hazardous to aquatic organisms [3].

A recent report on artificial food colors in grocery products marketed to children in North Carolina (USA) found that tartrazine was present in $20.5 \%$ of the products for consumption [4]. Tartrazine is a synthetic azodye used as a food colorant to achieve yellow or green shades in sweets, jellies, juices, jams, mustard, and sodas [5]. Additionally, it has been extensively used to dye human pharmaceuticals, such as vitamin capsules, antacids, and cosmetics $[5,6]$. Pharmaceutical manufacturers and distributors from Canada indicate that approximately 450 products contain tartrazine [7].

Toxicokinetic studies showed that less than $2 \%$ of ingested tartrazine is directly absorbed and most tartrazine is broken down into metabolites such as sulfanilic acid and aminopyrazolone in the colon $[8,9]$. A recent study showed clear absence of genotoxic activity for tartrazine in the bone marrow micronucleus assay and the Comet assay in the liver, stomach, and colon of mice [10]. However, as an azodye, tartrazine was subject to mutagenicity concern associated with the possible generation of free amines in vivo by azoreduction [11]. Other studies have reported that tartrazine may cause allergic reactions to some people, 
specifically those with asthma or aspirin intolerance [12]. It has been suggested that children with hyperactivity can develop increased irritability, restlessness, and sleep disturbances after taking tartrazine [13].

The high consumption of tartrazine is also guilty for high amounts of this dye to be lost during the processing of food and medicines, generating an environmental problem. Dyes are visible to the human eye, even in a low concentration $(<1 \mathrm{mg} / \mathrm{L})[1,14]$, and can reduce photosynthetic activity in aquatic environments by preventing the penetration of light and oxygen $[15,16]$. Therefore, food industries must treat their dye-containing effluents before discharging them into natural water sources.

Among various water treatment methods such as ion exchange, coagulation/flocculation, membrane filtration, reverse osmosis, chemical precipitation, advanced oxidation, and biological processes [3,15, 17-20], adsorption is one of the most widely used methods for the removal of dyes due to simplicity of design, low cost, easy operation, high efficiency, and reusability of material [20-25].

Various naturally occurring materials have been explored as adsorbents for the removal of dyes from wastewater [26-28], activated carbon being one of the most effective; however, it is not frequently used due to its high cost [29]. As an alternative to activated carbon, organic materials obtained from living or dead creatures (biomass) and agriculture waste have been used as low-cost adsorbents for the removal of pollution $[20,25,30]$.

Natural clays are considered to be excellent low-cost adsorbents for the removal of dyes from aqueous solutions due to their high surface area and porosity, layered structure, and high cation exchange capacity [31]. They include bentonite, montmorillonite, perlite, dolomite, illite, sepiolite, and kaolinite. The adsorption efficiency of clays is considerably enhanced after chemical modification through acid activation, thermal activation, intercalation and pillaring, surfactant treatment, and coating with metal oxide and clay composites made with different biopolymers $[3,24,32]$.

One of the most commonly used clays as an adsorbent is montmorillonite, a clay mineral member of the smectite group. The smectite layer structure is composed of two tetrahedral sheets packed in an octahedral sheet to form a TOT or 2:1 layer $[33,34]$. Isomorphic substitutions by lower-valence cations occurring in tetrahedral and/or octahedral sheets induce a net negative charge of the layer. This deficit is compensated by the presence of exchangeable cations in the interlayer space (commonly $\mathrm{Na}^{+}, \mathrm{K}^{+}$, and $\mathrm{Ca}^{2+}$ ). Although the adsorption capacity of montmorillonite for cations is very high, it is low for anions. This situation can be modified through an exchange of the inorganic cations with organic cations (surfactants), resulting in an organically modified clay mineral (so-called organoclay) [34-36]. The most common cationic surfactants used for clay modification are quaternary ammonium salts, such as HDTMA (hexadecyltrimethylammonium bromide), ODTMA (octadecyltrimethylammonium bromide), and TMAB (tetradecyltrimethylammonium bromide) [3]. This organically modified clay mineral has a high adsorption capacity for anionic dyes [37], acid dye (for example, methyl orange and acid red) $[38,39]$, and reactive dyes (such as remazol brilliant blue R) [40].

Raw bentonite possesses good adsorption properties of cationic dyes, but low adsorption affinity of anionic dyes (as tartrazine). Therefore, in this study, bentonite was modified with a cationic surfactant to incorporate positive charge sites for the adsorption of anionic species. Studies on the removal of tartrazine from a solution using a modified bentonite are limited [41]. In Colombia, it has been estimated that smectite clay deposits for exploitation are $1.1 \times 10^{9}$ metric tons [42], which could be used as an adsorbent material. This study evaluates the effect of variables $\mathrm{pH}$, ionic strength, agitation speed, adsorbent mass, and contact time on the adsorption of a tartrazine dye in an aqueous medium, using a Colombian bentonite modified with hexadecyltrimethylammonium bromide (HDTMA-Br) as the material adsorbent. Additionally, the effectiveness of the adsorbent to remove anionic dyes with a sample of wastewater from a local food industry was evaluated.

\section{Experimental}

2.1. Reagents and Materials. The azodye tartrazine $\left(\mathrm{C}_{16} \mathrm{H}_{9} \mathrm{~N}_{4} \mathrm{Na}_{3} \mathrm{O}_{9} \mathrm{~S}_{2}, 534.3 \mathrm{~g} / \mathrm{mol}\right.$, CAS registry number: $1934-$ 21-0) used in this study was of consumer quality (purity $62 \%$, $38 \% \mathrm{NaCl}$ and $\mathrm{NaSO}_{4}$ combined) purchased from Retema S.A.S.-Colombia, without further purification. The stock solution $(100 \mathrm{mg} / \mathrm{L})$ was prepared by accurately dissolving a weighed quantity of the dye in double-distilled water. An experimental dye solution in different concentrations was arranged by diluting the stock solution into a suitable volume of double-distilled water.

The surfactant hexadecyltrimenthylammonium bromide (denoted as HDTMA-Br, molecular formula: $\mathrm{CH}_{3}\left(\mathrm{CH}_{2}\right)_{15} \mathrm{~N}$ (Br) $\left(\mathrm{CH}_{3}\right)_{3}, 364.46 \mathrm{~g} / \mathrm{mol}$, CAS registry number: 57-09-0, purity $>98.0 \%$ ) was purchased from Panreac ${ }^{\circledR}$.

The clay used was a Colombian bentonite sample from Armero-Guayabal municipality in the north of the department of Tolima. The mineralogical and chemical composition of this bentonite has been previously reported [42]. The quantitative study for the mineral composition of the bentonite shows a content of montmorillonite $(48 \%)$, quartz $(21 \%)$, and plagioclase $(11 \%)$. The separation by particle size of the clay fraction $(<2 \mu \mathrm{m})$ was made by gravitational sedimentation and then, the purified bentonite was converted to sodium bentonite (denoted as Na-Bent) by two exchanges with the $\mathrm{NaCl}$ solution. The Na-Bent obtained was repeatedly washed with distilled water until the leachate showed a negative test for chloride ions, dried at $60^{\circ} \mathrm{C}$ and, finally, ground and sieved in a 100-mesh.

The cation exchange capacity (CEC) of Na-Bent was $41.16 \mathrm{meq} / 100 \mathrm{~g}$, determined by using the ammonium acetate method [43]. The chemical composition of the sodium bentonite (Na-Bent) obtained by XRF was 55.35\% $\mathrm{SiO}_{2}$, 16.28\% $\mathrm{Al}_{2} \mathrm{O}_{3}, 7.50 \% \mathrm{Fe}_{2} \mathrm{O}_{3}, 2.24 \% \mathrm{MgO}, 1.11 \% \mathrm{CaO}$, and $3.43 \% \mathrm{Na}_{2} \mathrm{O}$. 
2.2. Synthesis and Characterization of the Organobentonite. The total amount of the cationic surfactant used in the modification of the bentonite was 1.5 times the value of CEC, a value within the range recommended in the literature [44-46]. The modification included two steps. In the first step, the sodium bentonite was suspended in water $(50 \mathrm{~g} \mathrm{Na}-$ Bent in $1 \mathrm{~L}$ of distilled water) and left to stir for $12 \mathrm{~h}$ to achieve swelling. In the second step, a quaternary ammonium cation solution (12 g of HDTMA-Br in $500 \mathrm{~mL}$ of distilled water) was slowly added into the suspension containing the Na-Bent and vigorously stirred for $24 \mathrm{~h}$. The treated bentonite was separated from the suspension by centrifugation at $5000 \mathrm{rpm}$ and repeatedly washed until a negative bromide test with $0.1 \mathrm{M}$ of $\mathrm{AgNO}_{3}$ was obtained. The washed organobentonite was then dried in an oven at $80^{\circ} \mathrm{C}$ for $12 \mathrm{~h}$ and subsequently at $100^{\circ} \mathrm{C}$ for $2 \mathrm{~h}$. Finally, the organobentonite (denoted as HDTMA-Bent) was ground to obtain a particle size of 100 mesh.

Na-Bent and HDTMA-Bent were both characterized by $\mathrm{X}$-ray diffraction (XRD), content of total organic carbon (TOC), Fourier transform infrared spectroscopy (FT-IR), and nitrogen adsorption at $77 \mathrm{~K}$. The diffraction patterns were taken to a LabX Shimadzu XRD-6000 diffractometer with $\mathrm{Cu} \mathrm{K} \alpha$ radiation (steps of $0.022 \theta$ and 2 s/step). Total organic carbon was estimated by Multi N/C 3100 TOC analyzer (Analytik Jena, Germany) in a horizontal hightemperature oven HT1300 for solid sample analysis, equipped with a nondispersive infrared detector. The calibration was made with analytical-grade $\mathrm{CaCO}_{3}$. The calculated error for this technique was $\pm 0.20 \%$. Fourier transform infrared spectrometry (FT-IR) was recorded from samples pressed into pellets with $\mathrm{KBr}$ powder by using a Nicolet iS5 (Thermo Scientific). Nitrogen adsorption-desorption isotherms were determined in a Micromeritics ASAP 2020 instrument at $77 \mathrm{~K}$ after outgassing the samples for $3 \mathrm{~h}$ at $90^{\circ} \mathrm{C}$, followed by $2 \mathrm{~h}$ at $150^{\circ} \mathrm{C}$ in a vacuum.

2.3. Batch Adsorption Experiments. In the present study, batch adsorption experiments were carried out at ambient conditions $\left(20^{\circ} \mathrm{C}\right.$ and atmospheric pressure). For this, $50 \mathrm{~mL}$ solution of tartrazine at $20 \mathrm{mg} / \mathrm{L}$ were put into $100 \mathrm{~mL}$ Erlenmeyer flasks and an amount of organobentonite added to the solutions. The mixture was magnetically shaken at a constant speed using a 5-position digital magnetic hotplate stirrer (RT 5, IKA, Germany). The methodological design to evaluate the adsorption of tartrazine independently analyzed the effect of each factor ( $\mathrm{pH}$, ionic strength, agitation speed, adsorbent mass, and contact time), keeping the other parameters constant, as shown in Table 1 . The $\mathrm{pH}$ of the solution was adjusted with $0.1 \mathrm{~N} \mathrm{HCl}$ and $\mathrm{NaOH}$ solutions, and monitored with an SI Analytics Lab $845 \mathrm{pH}$ meter. The effect of the ionic strength on the adsorption process was evaluated at different concentrations of $\mathrm{NaCl}$ in the solution of tartrazine.

The dye concentration was determined from aliquots ( $1 \mathrm{~mL}$ of sample filtered in $0.45 \mu \mathrm{m}$ millipore paper), while the percentage of decolorization was established as a response variable (equation (1)), quantifying the dye concentration from a previous calibration curve, obtained by UV-Vis spectrophotometry (Mapada V-1200) at a wavelength $(\lambda)$ of $428 \mathrm{~nm}$ :

$$
\text { decolorization }(\%)=\frac{C_{o}-C_{t}}{C_{o}} \times 100,
$$

where $C_{o}$ and $C_{t}(\mathrm{mg} / \mathrm{L})$ are the liquid-phase concentrations of the dye at initial and any time $t$, respectively. All tests were performed in triplicate.

2.4. Experimental Design and Adsorption Isotherm. Based on the initial test of the methodological design (Table 1), the variables that mainly affect the adsorption process were defined, and an experimental design was established to determine the optimal conditions of adsorption.

The amount of tartrazine adsorbed at $20^{\circ} \mathrm{C}$ was evaluated at different initial concentrations of tartrazine ranging from 30 to $100 \mathrm{mg} / \mathrm{L}$ at the optimal conditions obtained from the experimental design. The adsorption capacity $\left(q_{e}, \mathrm{mg} / \mathrm{g}\right)$ of dye was calculated using the following equation:

$$
q_{e}=\frac{C_{o}-C_{e}}{W} \times V
$$

where $C_{o}$ and $C_{e}$ are the initial and equilibrium concentrations of the dye $(\mathrm{mg} / \mathrm{L})$, respectively, $V$ is the volume $(\mathrm{L})$, and $W$ is the mass $(\mathrm{g})$ of the adsorbent.

Adsorption isotherm data were fitted by the Freundlich and Langmuir models, which are the most frequently used. The Langmuir model assumes that there is no interaction between the adsorbate molecules and that the adsorption takes place in a monolayer $[47,48]$. The Langmuir isotherm is represented by the following equation:

$$
q_{e}=\frac{Q_{\max } K_{\mathrm{L}} C_{e}}{1+K_{\mathrm{L}} C_{e}},
$$

where $q_{e}$ is the adsorbate equilibrium amount in the solid phase $(\mathrm{mg} / \mathrm{g}), C_{e}$ is the adsorbate equilibrium concentrations in solution $(\mathrm{mg} / \mathrm{L}), Q_{\max }$ is the maximum adsorption capacity according to Langmuir monolayer adsorption (mg/g), and $K_{\mathrm{L}}$ is constant according to the Langmuir model (L/mg).

The Freundlich isotherm model is an empirical relationship describing the adsorption of solutes from a liquid to a solid surface, and it assumes that different sites with several adsorption energies are involved $[48,49]$. The form of the Freundlich equation is as follows:

$$
q_{e}=K_{\mathrm{F}} C_{e}^{1 / n}
$$

where $K_{\mathrm{F}}(\mathrm{L} / \mathrm{g})$ and $n$ are the Freundlich constants related to the adsorption capacity and adsorption intensity of the adsorbent, respectively.

2.5. Batch Adsorption Experiment with a Sample of Wastewater. The applicability of the adsorbent was evaluated in a sample of industrial wastewater taken from the washing process of a local industry in the food sector. The specifications given by the supplier of the sample correspond 
TABLE 1: The methodological design to evaluate the adsorption of tartrazine independently analyzed the effect of each factor.

\begin{tabular}{lccccc}
\hline Test & $\mathrm{pH}$ & Ionic strength $(\mathrm{NaCl}, \mathrm{M})$ & Agitation speed $(\mathrm{rpm})$ & $\begin{array}{c}\text { Adsorbent mass } \\
(\mathrm{mg})\end{array}$ & Contact time (min) \\
\hline 1 & $1,2,3,4,5,6,7,8,9,10,11$ & 0 & 300 & 25 & 60 \\
2 & 6 & $0,0.01,0.05,0.1$ & 300 & 25 & 60 \\
3 & 6 & 0 & $100,150,200,250,300$ & 25 & 60 \\
4 & 6 & 0 & 300 & $10,25,50,75,125$ & 60 \\
5 & 6 & 0 & 300 & 25 & $15,30,60,90,120,180,240$ \\
\hline
\end{tabular}

to an effluent rich in sugars, dyes (tartrazine and sunset yellow), and other compounds, with $\mathrm{pH}$ 3.5. Once the sample was obtained, a UV-Vis spectrum was performed to identify the wavelengths of maximum absorption, associated with the chromophore groups present in the sample.

\section{Results and Discussion}

3.1. Characterization of the Clay and Organoclay. Figure 1 shows the diffraction patterns of sodium bentonite and organobentonite. Na-Bent has a basal spacing $d_{001}$ at $15.4 \AA$, characteristic of a montmorillonite and, in HDTMA-Bent, it is increased to $22.3 \AA$. The intercalation of the $\mathrm{HDTMA}^{+}$ cations tends to maximize their contact with the silicate surface and, hence, the basal spacing increases as more quaternary ammonium cations are accommodated in the interlayer spaces [50]. Basal spacing of $21.7 \AA$ indicates that $\mathrm{HDTMA}^{+}$cations may intercalate as a pseudotrimolecular layer, while the basal spacing $>22.0 \AA$ is related to a paraffinlike arrangement, including tightly packed molecules inclined at a high angle towards the interlayer surface, with quaternary ammonium cations lying parallel to one another $[51,52]$. The basal spacing of $22.3 \AA$ obtained for organobentonite can be associated with the incorporation of the $\mathrm{HDTMA}^{+}$cation in a pseudotrilayer/paraffinic arrangement $[53,54]$. This was due to the charge heterogeneity of clay mineral layers [55].

The measured total organic carbon content of Na-Bent and HDTMA-Bent provided a measure of the quantity of quaternary organic cation intercalated into organoclay. The TOC for Na-Bent was $93.82 \pm 0.49 \mathrm{mg}$ of $\mathrm{C} / \mathrm{kg}$, a very low value that suggests a minimum amount of organic matter in the sample. The HDTMA-Bent showed a TOC of $113.85 \pm 1.85 \mathrm{~g}$ of $\mathrm{C} / \mathrm{kg}$ because the exchanged organic surfactant contained carbon in its structure. The incorporation of the $\mathrm{HDTMA}^{+}$cation in the clay was $77.68 \pm 1.30 \%$.

Figure 2 shows the FT-IR spectra for $\mathrm{Na}$-Bent and HDTMA-Bent. The two spectra show the presence of -OH as stretching bands at $3629 \mathrm{~cm}^{-1}$ as well as bending bands at $916 \mathrm{~cm}^{-1}$. The large band at $1035 \mathrm{~cm}^{-1}$ corresponds to the $\mathrm{Si}-$ $\mathrm{O}$ stretching vibration. Above signals can be considered characteristic of dioctahedral smectite $[42,56]$. Broad bands centered near 3422 and $1639 \mathrm{~cm}^{-1}$ are due to the $-\mathrm{OH}$ stretching mode of the interlayer water. The overlaid absorption peak in the region of $1639 \mathrm{~cm}^{-1}$ is assigned to the $-\mathrm{OH}$ bending mode of adsorbed water $[42,57]$. The band in the region of $875 \mathrm{~cm}^{-1}$ is due to the $\mathrm{Si}-\mathrm{O}-\mathrm{Al}$ stretching mode for montmorillonite [57, 58]. The bands at 794 and

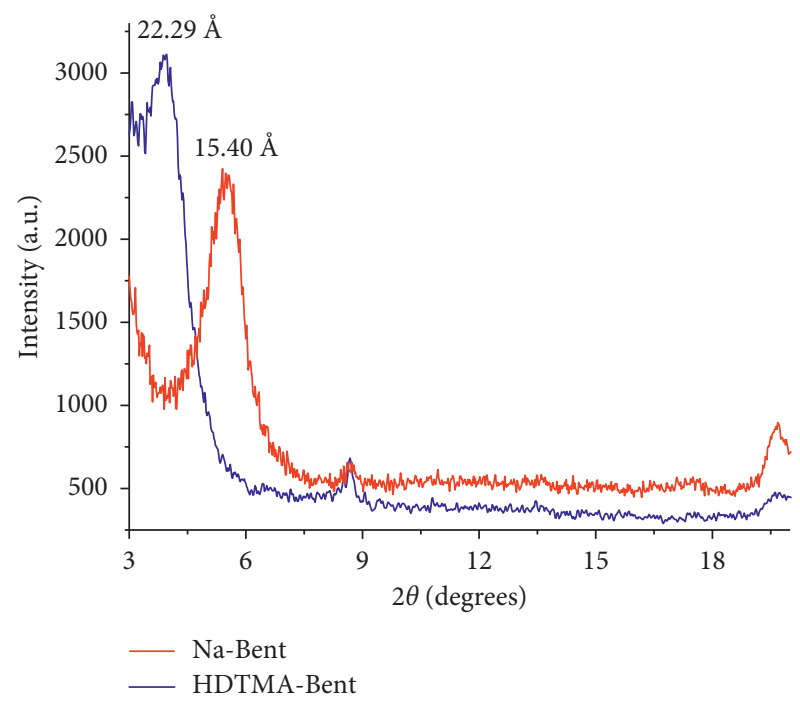

FIGURE 1: XRD patterns of sodium bentonite and organobentonite.

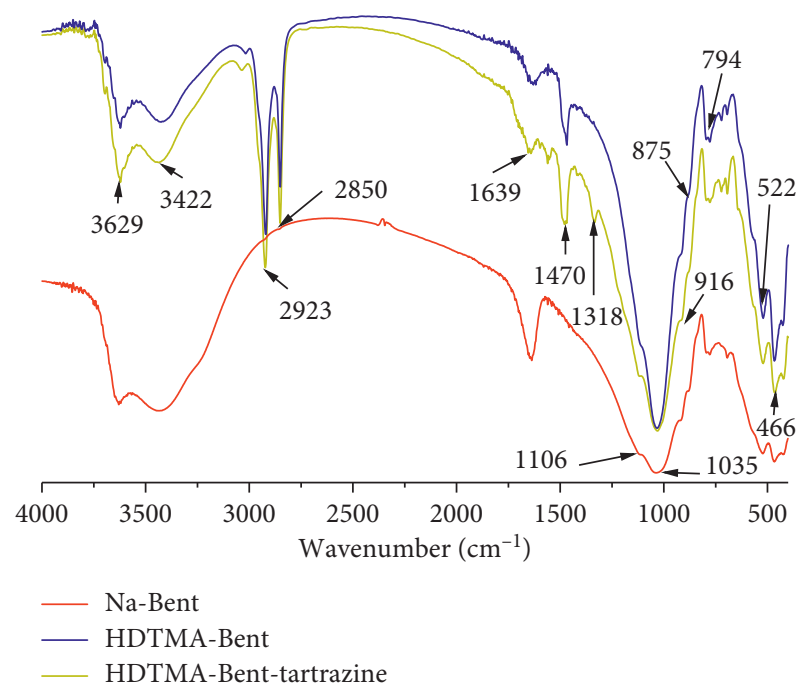

FIGURE 2: FT-IR spectra of sodium bentonite and the organobentonite before and after adsorption of tartrazine.

$1037 \mathrm{~cm}^{-1}$ correspond to $\mathrm{Si}-\mathrm{O}$ stretching vibration of quartz [59]. The bands at $522 \mathrm{~cm}^{-1}$ and $466 \mathrm{~cm}^{-1}$ are assigned to the $\mathrm{Si}-\mathrm{O}-\mathrm{Al}$ and $\mathrm{Si}-\mathrm{O}-\mathrm{Si}$ bending vibration, respectively $[57,58,60]$.

In the organobentonite, a pair of strong bands at 2850 and $2923 \mathrm{~cm}^{-1}$ was observed. These are assigned to the symmetric and asymmetric stretching vibrations of the 
methylene groups $\left(\mathrm{vCH}_{2}\right)$ and their bending vibration at $1470 \mathrm{~cm}^{-1}$ [61]. Previous bands are characteristic of bentonite modified with HDTMA [61, 62].

The adsorption-desorption isotherms of $\mathrm{N}_{2}$ at $77 \mathrm{~K}$ for $\mathrm{Na}-\mathrm{Bent}$ and HDTMA-Bent are shown in Figure 3. Na-Bent presented an isotherm type IVa with an $\mathrm{H} 3$ hysteresis loop. Type IVa isotherm is characteristic of mesoporous adsorbents, while $\mathrm{H} 3$ hysteresis loops are associated with nonrigid aggregates of plate-like particles [63]. The HDTMA-Bent isotherm could be a combination of type III and IVa, with a small hysteresis loop H3, characteristic of nonporous or macroporous solids.

The specific surface area calculated with the BET model for the Na-Bent was $62.9 \mathrm{~m}^{2} / \mathrm{g}$, of which $16.5 \mathrm{~m}^{2} / \mathrm{g}$ corresponds to the micropore area. The low specific surface area of the organobentonite $\left(3.2 \mathrm{~m}^{2} / \mathrm{g}\right)$ indicates that only a part of the surface was accessible to the nitrogen gas [64]. JacoboAzuara et al. found that the specific surface area of an organobentonite (bentonite from a deposit of San Luis Potosi, Mexico, modified with HDTMA) was $2 \mathrm{~m}^{2} / \mathrm{g}$ [65], similar to the value obtained in this study. Due to the intercalation of the $\mathrm{HDTMA}^{+}$cations in the interlaminar space of the bentonite in a paraffinic configuration, the pores are covered and there is a blockade that inhibits the passage of $\mathrm{N}_{2}$ molecules [44, 66].

3.2. Batch Adsorption Experiments. Figure 4 presents the results of the effect of $\mathrm{pH}$ and agitation speed on the adsorption of tartrazine, using HDTMA-Bent. Decolorization of the solution is not significantly affected in the range of $\mathrm{pH}$ from 2 to 9 , where the average removal was $99.07 \pm 0.93 \%$, this being a favorable aspect for the application of this material since the colored wastewater has $\mathrm{pH}$ values near 7 [67]. For a $\mathrm{pH}>9$, a negative effect on the removal of tartrazine was observed because, at high $\mathrm{pH}$ values, the electrostatic repulsion between the surface of the adsorbent, negatively charged, and the anionic dye reduces the adsorption capacity and removal of coloring $[68,69]$. Test of adsorption with $\mathrm{Na}$-Bent in the same range of $\mathrm{pH}$ showed no

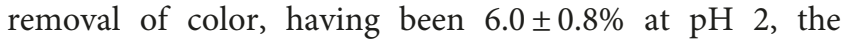
maximum value reached (results not shown in this work).

Less than $200 \mathrm{rpm}$ shaking speeds (Figure 4) fail to thoroughly mix the adsorbent with the solution, while 250 and $300 \mathrm{rpm}$ agitation speeds got decolorization higher to $97.33 \pm 0.49 \%$ and ensured uniformity in the medium [70]. Gautam et al. worked with similar agitation speeds (>180 rpm) for the adsorption of tartrazine on a copper coordinated dithiooxamide metal-organic framework $(\mathrm{Cu}-$ DTO MOF) [71].

The effect of the addition of $\mathrm{NaCl}$ and the amount of adsorbent in the removal of tartrazine on HDTMA-Bent are shown in Figure 5. The increase of the concentration of $\mathrm{NaCl}$ decreased the adsorption capacity of tartrazine from $97.85 \pm 2.74 \%$ of decolorization, in the absence of $\mathrm{NaCl}$, to $87.72 \pm 2.62 \%$, when the concentration of $\mathrm{NaCl}$ was $0.1 \mathrm{M}$. Monitoring of the ionic strength is important due to the fact that industrial wastewaters contain pollutants such as inorganic salts $\left(\mathrm{NaCl}, \mathrm{KCl}\right.$, and $\left.\mathrm{CaCl}_{2}\right)$ [27] that affect the

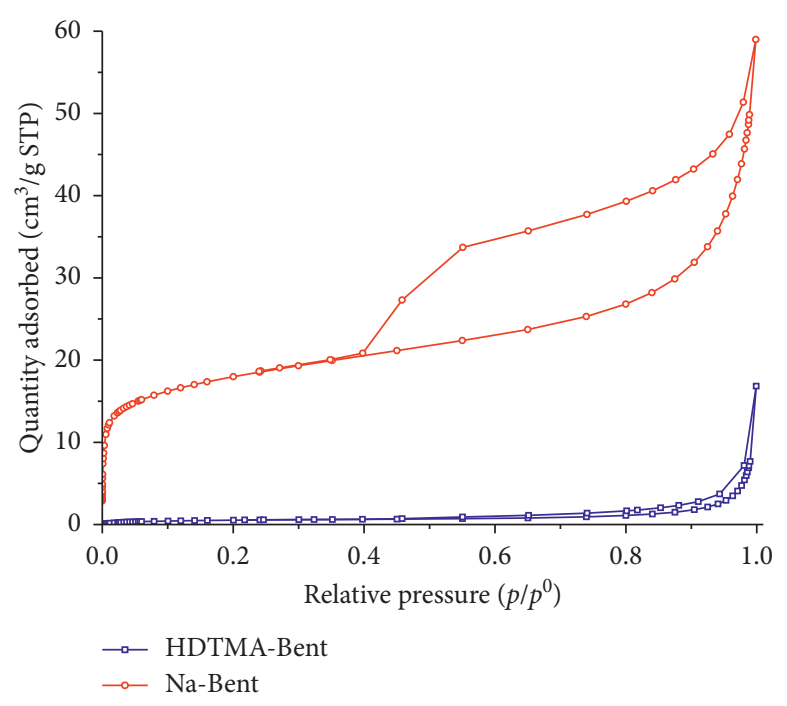

FIgURE 3: Nitrogen adsorption/desorption isotherms of sodium bentonite and organobentonite.

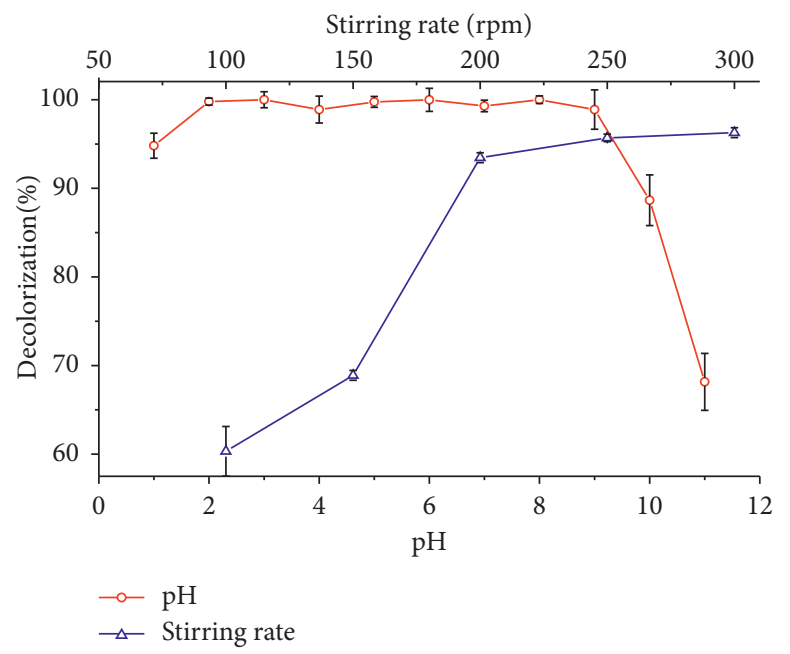

FIGURE 4: Effect of $\mathrm{pH}$ and the stirring rate on the adsorption of tartrazine on organobentonite.

adsorption of acid dyes such as tartrazine. The reason is, mainly, a competition between the $\mathrm{Cl}^{-}$ions and anions of tartrazine $\left(\mathrm{C}_{16} \mathrm{H}_{9} \mathrm{~N}_{4} \mathrm{O}_{9} \mathrm{~S}_{2}{ }^{3-}\right)$ as well as the difference in size between these two ions, which makes the $\mathrm{Cl}^{-}$ions to easily bind to the active sites of the adsorbent in comparison with the large-sized anions of tartrazine [71].

The effect of the amount of HDTMA-Bent in the decolorization of tartrazine is shown in Figure 5. For a mass of $10 \mathrm{mg}$ of adsorbent, the decolorization reached was low $(64.63 \pm 1.66 \%)$ due to the rapid saturation and limited availability of active sites in the adsorbent [27]. For a mass of $25 \mathrm{mg}$ HDTMA-Bent, the decolorization was $97.15 \pm 0.30 \%$ and, with an amount higher than $50 \mathrm{mg}$, the removal was kept constant in a $99.67 \pm 0.33 \%$. The increase of the decolorization of tartrazine obtained with greater amounts of adsorbent is associated with the existence of a greater number of active sites for the removal of dye [27, 72]. 


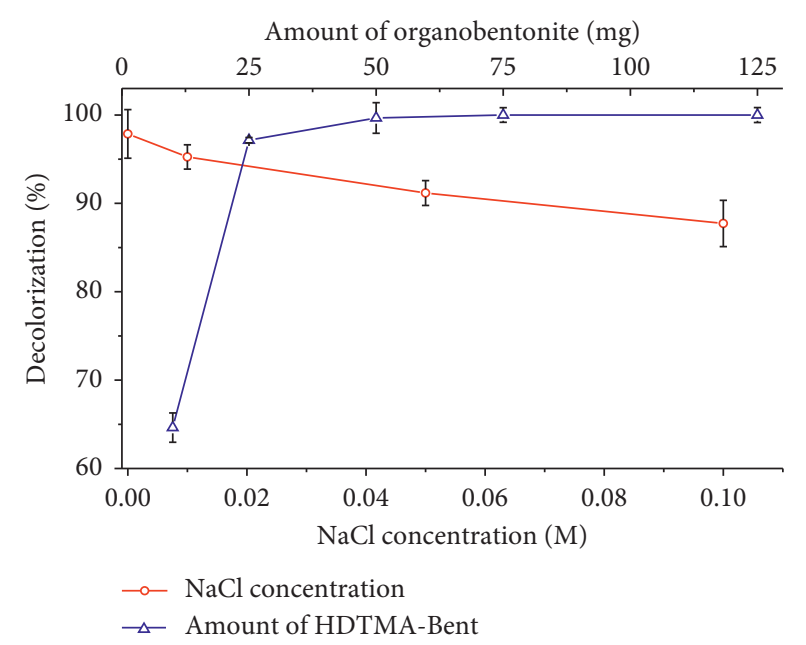

FIGURE 5: Effect of the addition of $\mathrm{NaCl}$ to the dye solution and amount of HDTMA-Bent on the adsorption of tartrazine.

Figure 6 presents the results of the contact time between the adsorbent and the solution of tartrazine. It was found that the adsorption process has two stages: the initial stage, which is rapid and occurs in the first $30 \mathrm{~min}$, implying strong electrostatic attractions between tartrazine and the organobentonite; the second stage is slow, and the adsorption tends to become stable (in equilibrium) after $60 \mathrm{~min}$ since it shows no considerable change in the decolorization, implying the saturation of active sites in the HDTMA-Bent $[27,73]$.

The FT-IR spectrum of the adsorbent after the removal of tartrazine at $120 \mathrm{~min}$ shows an additional signal at $1318 \mathrm{~cm}^{-1}$ (Figure 2), which is associated with the C-N stretching of the structure of tartrazine [71].

From the analysis of the results of the parameters that affected the adsorption of tartrazine on the organobentonite, it was established that the main variables that affected the process were the amount of adsorbent and the addition of $\mathrm{NaCl}$ to the dye solution. $\mathrm{pH}$ values between 2 and 9, stirring speed above $200 \mathrm{rpm}$, and contact time of $60 \mathrm{~min}$ did not have a significant effect on decolorization.

3.3. Experimental Design. With the results of the initial tests of the methodological design (Table 1), a complete factorial design $3^{2}$ was established, having the amount of adsorbent $(A)$ and the concentration of tartrazine $(B)$ as variables. The levels for $A$ and $B$ were 25,35 , and $45 \mathrm{mg}$ and 30,40 , and $50 \mathrm{mg} / \mathrm{L}$, respectively. All the experiments were carried out in triplicate and were kept constant: $\mathrm{pH}=6$, contact time $=60 \mathrm{~min}$, concentration of $\mathrm{NaCl}=0.1 \mathrm{M}$, and agitation speed $=230 \mathrm{rpm}$. The response variable was decolorization percentage (\%). Experimental data were evaluated with a Design Expert ${ }^{\circledR}$ software version 8.0 (StatEase, Inc., Minneapolis, MN, USA) using a response surface methodology (RSM) in order to obtain the interaction between the processed variables and the response. Data were adjusted to a second-order polynomial equation to determine the coefficients of the response model as well as their standard

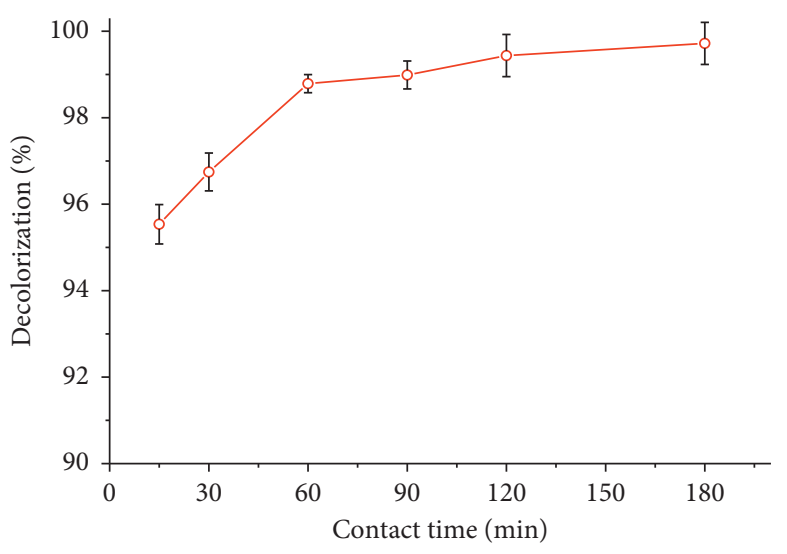

FIgURE 6: Effect of time contact on the adsorption of tartrazine on organobentonite.

errors and significance [74]. For the two variable inputs under consideration, the response model is as shown in the following equation:

$$
Y=\beta_{0}+\sum_{i=1}^{k} \beta_{i} X_{i}+\sum_{i=1}^{k} \beta_{i i} X_{i}^{2} \sum_{i=1}^{k-1} \sum_{\substack{j=2 \\ j>i}}^{k} \beta_{i j} X_{i} X_{j}
$$

where $Y$ is the predicted response (decolorization, $\%$ ); $\beta_{0}, \beta_{i}$, $\beta_{i i}$, and $\beta_{i j}$ are the regression coefficients for the intercept and the linear, quadratic, and interaction coefficients, respectively; $X_{i}$ and $X_{j}$ are the independent variables, and $k=2$, i.e., the number of independent variables. The quality of the model fits was evaluated by the coefficients of determination $\left(R^{2}\right.$ and adjusted $\left.R_{\text {adj }}^{2}\right)$ and analysis of variance (ANOVA).

Table 2 shows the codified and experimental values of the runs performed in the experimental design along with the response observed (average of the three repetitions).

The ANOVA results are shown in Table 3. The model and coefficients were considered significant for a $p$ value $<$ of 0.05 .

Data in Table 3 indicate that the model and parameters are significant. The $p$ values show that coefficients of the main effects are highly significant $(p<0.0001)$, compared to the interaction effect. The second-order response function representing the relationship between the decolorization (\%) and the independent variables appears in the following equation:

$$
\begin{aligned}
\text { decolorization }(\%)= & -137.17276+10.31623 A \\
& +2.67123 B-0.05194 A B \\
& -0.09737 A^{2}-0.03913 B^{2} .
\end{aligned}
$$

All first-order coefficients of the model for the response decolorization showed positive effects, whereas the quadratic and interaction coefficients had a negative effect. Coefficients of determination $\left(R^{2}\right)$ and adjusted $R_{\text {adj }}^{2}$ of the model were 0.9710 and 0.9640 , respectively, evidencing that this regression is statistically significant and that only $3.60 \%$ 
TABLE 2: Factorial design for the independent variables used in this study along with the observed response.

\begin{tabular}{lccccc}
\hline & \multicolumn{2}{c}{ Code } & \multicolumn{2}{c}{ Real values } & Response \\
Test & \multicolumn{2}{c}{ values } & \multicolumn{2}{c}{ ( } & D \\
& $A$ & $B$ & $A(\mathrm{mg})$ & $B(\mathrm{mg} / \mathrm{L})$ & Decolorization, (\%) \\
\hline 1 & -1 & -1 & 25 & 30 & $63.72 \pm 1.67$ \\
2 & 0 & -1 & 35 & 30 & $99.99 \pm 0.01$ \\
3 & 1 & -1 & 45 & 30 & $99.99 \pm 0.02$ \\
4 & -1 & 0 & 25 & 40 & $50.36 \pm 0.38$ \\
5 & 0 & 0 & 35 & 40 & $71.02 \pm 0.68$ \\
6 & 1 & 0 & 45 & 40 & $87.59 \pm 1.44$ \\
7 & -1 & 1 & 25 & 50 & $32.82 \pm 0.36$ \\
8 & 0 & 1 & 35 & 50 & $49.58 \pm 0.84$ \\
9 & 1 & 1 & 45 & 50 & $46.50 \pm 0.61$ \\
\hline
\end{tabular}

TABLe 3: Results of regression analysis (ANOVA).

\begin{tabular}{lccccc}
\hline Source & Sum of square & DF & Mean square & $F$ value & $p$ value \\
\hline Model & 13962.18 & 5 & 2792.44 & 140.40 & $<0.0001$ \\
$A$ & 3644.00 & 1 & 3644.00 & 183.22 & $<0.0001$ \\
$B$ & 9333.73 & 1 & 9333.73 & 469.30 & $<0.0001$ \\
$\mathrm{AB}$ & 323.76 & 1 & 323.76 & 16.28 & $<0.05$ \\
$A^{2}$ & 568.82 & 1 & 568.82 & 28.60 & $<0.0001$ \\
$B^{2}$ & 91.87 & 1 & 91.87 & 4.62 & $<0.05$ \\
\hline
\end{tabular}

of the total variations are not explained by the model $[70,75]$.

Figure 7 shows the contour plot that represents the interaction of the independent variables (dye concentration and amount of adsorbent). It illustrates that the decolorization has a tendency to decrease, when increasing the concentration of tartrazine and decreasing the amount of HDTMA-Bent. A region is also observed where the model establishes a complete decolorization when the dye concentration is lower than $33 \mathrm{mg} / \mathrm{L}$ and the amount of the adsorbent is greater than $37 \mathrm{mg}$.

To confirm the results obtained with the mathematical model presented in equation (6) of the experimental design, additional adsorption tests were carried out. The points were taken within the design range and classified as low, medium, and high with respect to the response (decolorization). The experiments were carried out in triplicate, at the same conditions in which the model was obtained $(\mathrm{pH}=6, \mathrm{NaCl}$ concentration $=0.1 \mathrm{M}$, contact time $=60 \mathrm{~min}$, and agitation speed $=230 \mathrm{rpm}$ ).

From the results presented in Table 4, it is observed that, for the three points evaluated, the maximum difference between the experimental value and the one calculated with equation (6) was $4.8 \%$. Therefore, the model obtained can be used to predict the response of the system with minimal variations.

A numerical optimization was performed for the factors and the response of the experimental design. The criteria selected in the software to perform the optimization were to minimize the amount of the adsorbent and maximize the decolorization. A higher degree of importance was assigned to the response because it is the main objective of the process. Figure 8 shows the best scenario for the combined

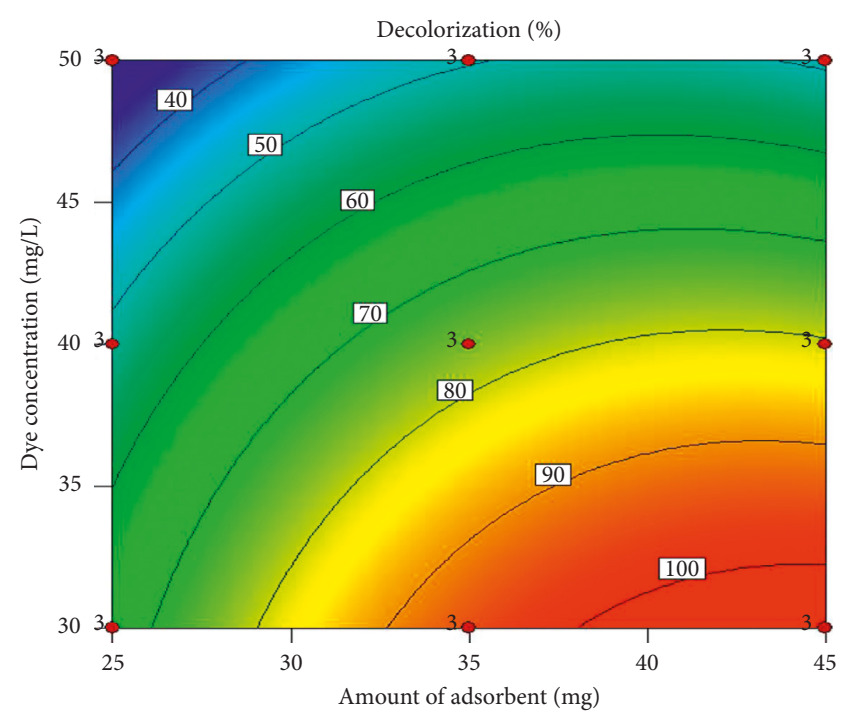

FIgURe 7: Contour plot for decolorization of tartrazine vs dye concentration and amount of adsorbent.

TABle 4: Points for the validation of the experimental design.

\begin{tabular}{|c|c|c|c|c|}
\hline \multirow{2}{*}{$\begin{array}{l}\text { Adsorbent } \\
(\mathrm{mg})\end{array}$} & \multirow{2}{*}{$\begin{array}{c}\text { Dye } \\
\text { concentration } \\
(\mathrm{mg} / \mathrm{L})\end{array}$} & \multicolumn{2}{|c|}{ Decolorization (\%) } & \multirow{2}{*}{$\begin{array}{c}\text { Error } \\
(\%)\end{array}$} \\
\hline & & Experimental & Calculated & \\
\hline 27 & & & & 4.79 \\
\hline 40 & & $69.15 \pm$ & 70.78 & 2.31 \\
\hline 36 & 34.58 & $92.73 \pm 0.14$ & 88.93 & 4.27 \\
\hline
\end{tabular}

criteria in a function of global desirability, where the maximum decolorization $(100 \%)$ is reached when the amount of adsorbent is $38.04 \mathrm{mg}$ and the concentration of the dye is $30 \mathrm{mg} / \mathrm{L}$, with a desirability of 0.839 . The function of desirability varies between zero, which is outside the limit, and one, which is the goal, and indicates how close the lower and upper limits of the factors were established in relation with the actual optimum value [70].

The tartrazine adsorption isotherm at $20^{\circ} \mathrm{C}$ was evaluated at dye concentrations of $30,40,50,60,70,80,90$, and $100 \mathrm{mg} / \mathrm{L}$ with an amount of organobentonite $=0.45 \mathrm{~g}$ and the same experimental conditions used for obtaining the model $(V=50 \mathrm{~mL}, \mathrm{pH}=6.0, \mathrm{NaCl}$ concentration $=0.1 \mathrm{M}$, contact time $=60 \mathrm{~min}$, and agitation speed $=230 \mathrm{rpm}$ ). The data obtained from the adsorption isotherm were fitted to the nonlinear form of Langmuir and Freundlich models using equations (3) and (4), respectively (Figure 9). Parameters of the fit were determined and are presented in Table 5.

The high value of the correlation coefficient obtained for the adsorption of tartrazine onto organobentonite indicates that the Freundlich model $\left(r^{2}=0.988\right)$ can be applied to this system better than the Langmuir model $\left(r^{2}=0.916\right)$, indicating a heterogeneous adsorption surface instead of a homogeneous monolayer adsorption as predicted by the Langmuir adsorption model. The $K_{\mathrm{F}}$ and $n$ values calculated from the Freundlich isotherm were $33.02 \pm 0.27 \mathrm{~L} / \mathrm{g}$ and $17.64 \pm 0.89$, respectively. The high value of $n$ confirms the heterogeneous adsorption system as predicted by the 


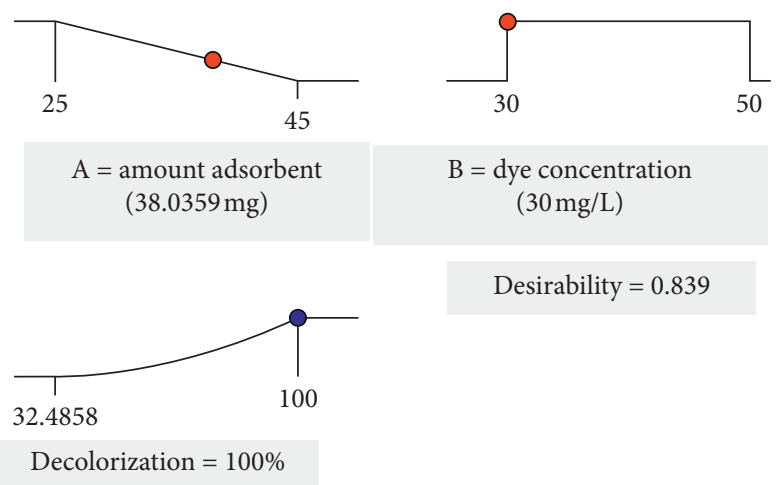

FIGURE 8: Desirability ramp for numerical optimization of decolorization.

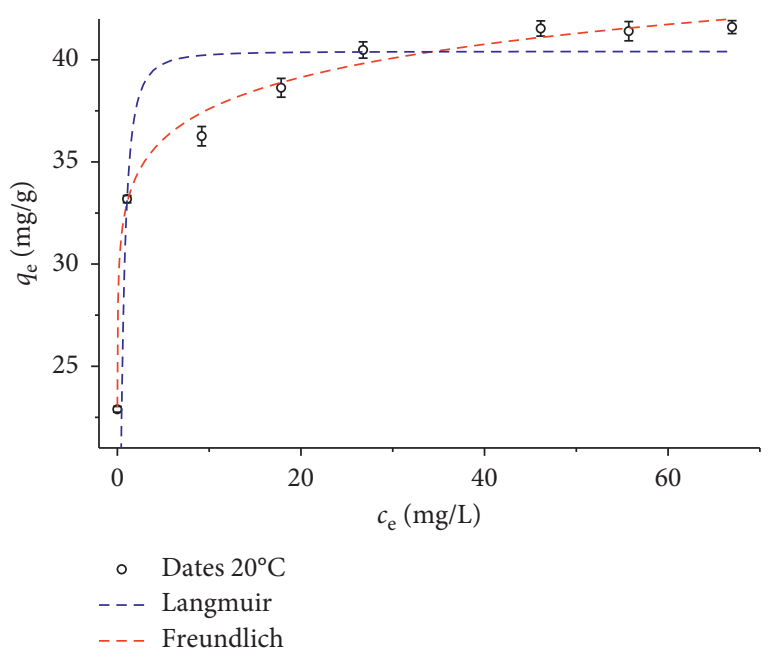

FIGURE 9: Adsorption isotherm of tartrazine onto HDTMA-Bent at $20^{\circ} \mathrm{C}$.

TABLE 5: Equilibrium isotherm parameters for the adsorption of tartrazine onto organobentonite.

\begin{tabular}{lcc}
\hline \multirow{3}{*}{ Langmuir } & $Q_{\max }(\mathrm{mg} / \mathrm{g})$ & $40.79 \pm 0.71$ \\
& $K_{\mathrm{L}}(\mathrm{L} / \mathrm{mg})$ & $4.06 \pm 0.62$ \\
& $r^{2}$ & 0.916 \\
\hline \multirow{3}{*}{ Freundlich } & $K_{\mathrm{F}}(\mathrm{L} / \mathrm{g})$ & $33.02 \pm 0.27$ \\
& $n$ & $17.64 \pm 0.89$ \\
& $r^{2}$ & 0.988 \\
\hline
\end{tabular}

Freundlich adsorption model and the efficiency of HDTMABent as a material adsorbent toward tartrazine removal. The maximum adsorption capacity of tartrazine obtained in this study was compared with that of other adsorbents in the literature, as shown in Table 6. The HDTMA-Bent showed a value of adsorption capacity similar to that of a bentonite modified with octadecyltrimethylammonium and superior to that of other low-cost adsorbents such as sawdust and chitin.

3.4. Batch Adsorption Experiment with a Sample of Wastewater. Figure 10 showed the UV-Vis of the sample of the wastewater before and after the adsorption with Bent-
TABLE 6: Comparison of the adsorption capacity of organobentonite with various adsorbents.

\begin{tabular}{lcc}
\hline Adsorbent & $\begin{array}{c}Q_{\max } \\
(\mathrm{mg} / \mathrm{g})\end{array}$ & Reference \\
\hline Polyaniline-sawdust composite (PAni/SD) & 2.45 & {$[76]$} \\
Sawdust & 4.71 & {$[77]$} \\
Chitin & 30.00 & {$[78]$} \\
Organobentonite (HDTMA-Bent) & 40.79 & This \\
Organobentonite (1CEC-NaB) & 43.3 & {$[41]$} \\
Carbon nanotubes (CNTs) & 52.24 & {$[79]$} \\
Hen feather & 64.1 & {$[80]$} \\
Nigerian soil & 83.33 & {$[81]$} \\
Cross-linked chitosan-coated bentonite & 294.1 & {$[82]$} \\
(CCB) & & \\
\hline
\end{tabular}

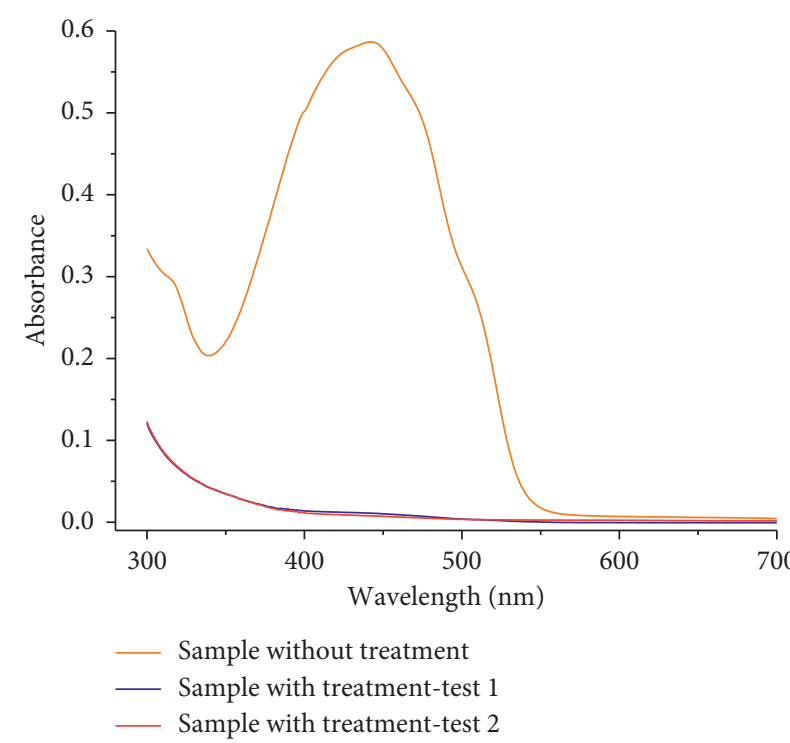

FIGURE 10: UV-Vis spectra of wastewater sample before and after adsorption.

HDTMA (duplicate). The test conditions were as follows: volume of solution $=50 \mathrm{~mL}$, amount of adsorbent $=45 \mathrm{mg}$, $\mathrm{pH}=6$, contact time $=60 \mathrm{~min}$, concentration of $\mathrm{NaCl}=0.1 \mathrm{M}$, and agitation speed $=230 \mathrm{rpm}$. In the untreated wastewater sample, a pronounced and wide signal was observed, between 350 and $540 \mathrm{~nm}$, corresponding to the maximum adsorption wavelengths of tartrazine $(428 \mathrm{~nm})$ and sunset yellow $(482 \mathrm{~nm})$. The average decolorization of tartrazine and sunset yellow was 98.19 and $98.76 \%$, respectively. Considering that sunset yellow is an azodye $\left(\mathrm{C}_{16} \mathrm{H}_{10} \mathrm{~N}_{2} \mathrm{Na}_{2} \mathrm{O}_{7} \mathrm{~S}_{2}\right)$, anionic, with characteristics similar to tartrazine, it is concluded that the Bent-HDTMA adsorbent was efficient in the removal of both dyes, although it was not selective.

\section{Conclusions}

In this study, a Colombian bentonite was modified with HDTMA-Br and used to remove tartrazine from an aqueous solution, obtaining high levels of decolorization, with the 
advantage of using a natural, abundant, and low-cost material.

It was established that the main variables that affect the adsorption of tartrazine were the amount of adsorption and the addition of $\mathrm{NaCl}$ to the dye solution. $\mathrm{pH}$ values between 2 and 9, stirring speed above $200 \mathrm{rpm}$, and contact time of $60 \mathrm{~min}$ did not have a significant effect on decolorization.

To achieve the total decolorization of a $30 \mathrm{mg} / \mathrm{L}$ tartrazine aqueous solution, $38.04 \mathrm{mg}$ of HDTMA-Bent was required under the following conditions: $\mathrm{pH}=6.0, \mathrm{NaCl}$ concentration $=0.1 \mathrm{M}$, stirring speed $=230 \mathrm{rpm}$, temperature $=20^{\circ} \mathrm{C}$, and contact time $=60 \mathrm{~min}$.

\section{Data Availability}

The data that support the characterization results of the adsorbent (XRD, FT-IR, and N2 adsorption/desorption) and the batch adsorption experiments appear in the document in the form of figures and tables. All the data are available.

\section{Conflicts of Interest}

The authors declare that they have no conflicts of interest.

\section{Acknowledgments}

We gratefully acknowledge the financial support of Universidad Nacional de Colombia Sede Manizales through the project DIMA-UNAL (Code 38719).

\section{References}

[1] Y. Al-Degs, M. A. M. Khraisheh, S. J. Allen, and M. N. A. Ahmad, "Sorption behavior of cationic and anionic dyes from aqueous solution on different types of activated carbons," Separation Science and Technology, vol. 36, no. 1, pp. 91-102, 2001.

[2] S. Kim, C. M. Park, M. Jang et al., "Aqueous removal of inorganic and organic contaminants by graphene-based nanoadsorbents: a review," Chemosphere, vol. 212, pp. 1104-1124, 2018.

[3] S. Ismadji, F. Edi Soetaredjo, and A. Ayucitra, Clay Materials for Environmental Remediation, Springer International Publishing, Cham, Switzerland, 2015.

[4] A. Batada and M. F. Jacobson, "Prevalence of artificial food colors in grocery store products marketed to children," Clinical Pediatrics, vol. 55, no. 12, pp. 1113-1119, 2016.

[5] Y. M. Abd-Elhakim, M. M. Hashem, A. E. El-Metwally et al., "Comparative haemato-immunotoxic impacts of long-term exposure to tartrazine and chlorophyll in rats," International Immunopharmacology, vol. 63, pp. 145-154, 2018.

[6] K. V. Allam and G. P. Kumar, "Colorants-The cosmetics for the pharmaceutical dosage forms," International Journal of Pharmacy and Pharmaceutical Sciences, vol. 3, no. 3, pp. 13-21, 2011.

[7] M. E. MacCara, "Tartrazine: a potentially hazardous dye in Canadian drugs," Canadian Medical Association Journal, vol. 126, no. 8, pp. 910-914, 1982.

[8] M. O. Elhkim, F. Héraud, N. Bemrah et al., "New considerations regarding the risk assessment on tartrazine," Regulatory Toxicology and Pharmacology, vol. 47, no. 3, pp. 308-316, 2007.
[9] R. D. Murdoch, I. Pollock, and S. Naeem, "Tartrazine induced histamine release in vivo in normal subjects," Journal of the Royal College of Physicians of London, vol. 21, no. 4, pp. 257-261, 1987.

[10] M. Bastaki, T. Farrell, S. Bhusari, K. Pant, and R. Kulkarni, "Lack of genotoxicity in vivo for food color additive tartrazine," Food and Chemical Toxicology, vol. 105, pp. 278-284, 2017.

[11] M. J. Prival and V. D. Mitchell, "Analysis of a method for testing azo dyes for mutagenic activity in Salmonella typhimurium in the presence of flavin mononucleotide and hamster liver S9," Mutation Research/Environmental Mutagenesis and Related Subjects, vol. 97, no. 2, pp. 103-116, 1982.

[12] I. Grzelewska-Rzymowska, M. Szmidt, M. Kowalski, and J. Roźniecki, "Sensitivity and tolerance to tartrazine in aspirinsensitive asthmatics," Allergologia et Immunopathologia, vol. 14, no. 1, pp. 31-36, 1986.

[13] K. S. Rowe and K. J. Rowe, "Synthetic food coloring and behavior: a dose response effect in a double-blind, placebocontrolled, repeated-measures study," The Journal of Pediatrics, vol. 125, no. 5, pp. 691-698, 1994.

[14] K.-T. Chung, "The significance of azo-reduction in the mutagenesis and carcinogenesis of azo dyes," Mutation Research/ Reviews in Genetic Toxicology, vol. 114, no. 3, pp. 269-281, 1983.

[15] M. Vakili, M. Rafatullah, B. Salamatinia et al., "Application of chitosan and its derivatives as adsorbents for dye removal from water and wastewater: a review," Carbohydrate Polymers, vol. 113, pp. 115-130, 2014.

[16] G. Crini, "Non-conventional low-cost adsorbents for dye removal: a review," Bioresource Technology, vol. 97, no. 9, pp. 1061-1085, 2006.

[17] A. Ahmad, S. H. Mohd-Setapar, C. S. Chuong et al., "Recent advances in new generation dye removal technologies: novel search for approaches to reprocess wastewater," RSC Advances, vol. 5, no. 39, pp. 30801-30818, 2015.

[18] C. R. Holkar, A. J. Jadhav, D. V. Pinjari, N. M. Mahamuni, and A. B. Pandit, "A critical review on textile wastewater treatments: possible approaches," Journal of Environmental Management, vol. 182, pp. 351-366, 2016.

[19] V. Katheresan, J. Kansedo, and S. Y. Lau, "Efficiency of various recent wastewater dye removal methods: a review," Journal of Environmental Chemical Engineering, vol. 6, no. 4, pp. 4676-4697, 2018.

[20] T. Ahmad, M. Danish, M. Rafatullah et al., "The use of date palm as a potential adsorbent for wastewater treatment: a review," Environmental Science and Pollution Research, vol. 19, no. 5, pp. 1464-1484, 2012.

[21] T. A. Khan, E. A. Khan, and Shahjahan, "Adsorptive uptake of basic dyes from aqueous solution by novel brown linseed deoiled cake activated carbon: equilibrium isotherms and dynamics," Journal of Environmental Chemical Engineering, vol. 4, no. 3, pp. 3084-3095, 2016.

[22] E. A. Khan, Shahjahan, and T. A. Khan, "Adsorption of methyl red on activated carbon derived from custard apple (Annona squamosa) fruit shell: equilibrium isotherm and kinetic studies," Journal of Molecular Liquids, vol. 249, pp. 1195-1211, 2018.

[23] T. A. Khan, R. Rahman, and E. A. Khan, "Adsorption of malachite green and methyl orange onto waste tyre activated carbon using batch and fixed-bed techniques: isotherm and kinetics modeling," Modeling Earth Systems and Environment, vol. 3, no. 38, pp. 1-14, 2017. 
[24] T. A. Khan, E. A. Khan, and Shahjahan, "Removal of basic dyes from aqueous solution by adsorption onto binary ironmanganese oxide coated kaolinite: non-linear isotherm and kinetics modeling," Applied Clay Science, vol. 107, pp. 70-77, 2015.

[25] M. Vakili, M. Rafatullah, M. H. Ibrahim, A. Z. Abdullah, B. Salamatinia, and Z. Gholami, "Chitosan hydrogel beads impregnated with hexadecylamine for improved reactive blue 4 adsorption," Carbohydrate Polymers, vol. 137, pp. 139-146, 2016.

[26] I. Ali, M. Asim, and T. A. Khan, "Low cost adsorbents for the removal of organic pollutants from wastewater," Journal of Environmental Management, vol. 113, pp. 170-183, 2012.

[27] T. Ngulube, J. R. Gumbo, V. Masindi, and A. Maity, "An update on synthetic dyes adsorption onto clay based minerals: a state-of-art review," Journal of Environmental Management, vol. 191, pp. 35-57, 2017.

[28] M. Rafatullah, O. Sulaiman, R. Hashim, and A. Ahmad, "Adsorption of methylene blue on low-cost adsorbents: a review," Journal of Hazardous Materials, vol. 177, no. 1-3, pp. 70-80, 2010.

[29] T. Robinson, G. McMullan, R. Marchant, and P. Nigam, "Remediation of dyes in textile effluent: a critical review on current treatment technologies with a proposed alternative," Bioresource Technology, vol. 77, no. 3, pp. 247-255, 2001.

[30] T. Ahmad, M. Rafatullah, A. Ghazali, O. Sulaiman, and R. Hashim, "Oil palm biomass-based adsorbents for the removal of water pollutants-a review," Journal of Environmental Science and Health, Part C, vol. 29, no. 3, pp. 177-222, 2011.

[31] T. A. Khan, S. Dahiya, and E. A. Khan, "Removal of direct red 81 from aqueous solution by adsorption onto magnesium oxide-coated kaolinite: isotherm, dynamics and thermodynamic studies," Environmental Progress \& Sustainable Energy, vol. 36, no. 1, pp. 45-58, 2017.

[32] T. A. Khan, S. Dahiya, and I. Ali, "Use of kaolinite as adsorbent: equilibrium, dynamics and thermodynamic studies on the adsorption of rhodamine B from aqueous solution," Applied Clay Science, vol. 69, pp. 58-66, 2012.

[33] M. F. Brigatti, E. Galan, and B. K. G. Theng, "Chapter 2. Structures and mineralogy of clay minerals," in Handbook of Clay Science, Vol. 1 of Developments in Clay Science, pp. 19-86, Elsevier, Oxford, UK, 2006.

[34] J. Wang, K. Sun, W. Hao, Y. Du, and C. Pan, "Structure and properties research on montmorillonite modified by flameretardant dendrimer," Applied Clay Science, vol. 90, pp. 109-121, 2014.

[35] F. Bergaya and G. Lagaly, "Chapter 1. Introduction to clay science: techniques and applications," in Handbook of Clay Science, Vol. 1 of Developments in Clay Science, pp. 1-18, Elsevier, Oxford, UK, 2006.

[36] J. F. Lambert and F. Bergaya, "Chapter 13.1. Smectitepolymer nanocomposites," in Handbook of Clay Science, Vol. 5 of Developments in Clay Science, pp. 679-706, Elsevier, Oxford, UK, 2013.

[37] A. Kausar, M. Iqbal, A. Javed et al., "Dyes adsorption using clay and modified clay: a review," Journal of Molecular Liquids, vol. 256, pp. 395-407, 2018.

[38] Z. Luo, M. Gao, Y. Ye, and S. Yang, "Modification of reducedcharge montmorillonites by a series of Gemini surfactants: characterization and application in methyl orange removal," Applied Surface Science, vol. 324, pp. 807-816, 2015.

[39] M. D. Mullassery, N. B. Fernandez, and T. S. Anirudhan, "Adsorptive removal of acid red from aqueous solutions by cationic surfactant-modified bentonite clay," Desalination and Water Treatment, vol. 56, no. 7, pp. 1929-1939, 2015.

[40] D. F. Brito, E. C. da Silva Filho, M. G. Fonseca, and M. Jaber, "Organophilic bentonites obtained by microwave heating as adsorbents for anionic dyes," Journal of Environmental Chemical Engineering, vol. 6, no. 6, pp. 7080-7090, 2018.

[41] S. Sahnoun, M. Boutahala, C. Tiar, and A. Kahoul, "Adsorption of tartrazine from an aqueous solution by octadecyltrimethylammonium bromide-modified bentonite: kinetics and isotherm modeling," Comptes Rendus Chimie, vol. 21, no. 3-4, pp. 391-398, 2018.

[42] I. F. Macías-Quiroga, G. I. Giraldo-Gómez, and N. R. Sanabria-González, "Characterization of colombian clay and its potential use as adsorbent," The Scientific World Journal, vol. 2018, Article ID 5969178, 11 pages, 2018.

[43] A. G. Norman and H. Chapman, "Cation-exchange capacity," in Methods of Soil Analysis, Part 2. Chemical and Microbiological Properties, pp. 891-901, American Society of Agronomy, Inc., Madison, WI, USA, 1965.

[44] B. Erdem, A. S. Özcan, and A. Özcan, "Preparation of HDTMA-bentonite: characterization studies and its adsorption behavior toward dibenzofuran," Surface and Interface Analysis, vol. 42, no. 6-7, pp. 1351-1356, 2010.

[45] S. Gammoudi, N. Frini-Srasra, and E. Srasra, "Influence of exchangeable cation of smectite on HDTMA adsorption: equilibrium, kinetic and thermodynamic studies," Applied Clay Science, vol. 69, pp. 99-107, 2012.

[46] R. Koswojo, R. P. Utomo, Y.-H. Ju et al., "Acid green 25 removal from wastewater by organo-bentonite from Pacitan," Applied Clay Science, vol. 48, no. 1-2, pp. 81-86, 2010.

[47] I. Langmuir, "The constitution and fundamental properties of solids and liquids. Part I. Solids," Journal of the American Chemical Society, vol. 38, no. 11, pp. 2221-2295, 1916.

[48] K. Y. Foo and B. H. Hameed, "Insights into the modeling of adsorption isotherm systems," Chemical Engineering Journal, vol. 156, no. 1, pp. 2-10, 2010.

[49] H. M. F. Freundlich, "Over the adsorption in solution," The Journal of Physical Chemistry, vol. 57, pp. 385-471, 1906.

[50] S. H. Xu, G. Y. Sheng, and S. A. Boyd, "Use of organoclays in pollution abatement," in Advances in Agronomy, vol. 59, pp. 25-62, Academic Press, Inc., San Diego, CA, USA, 1997.

[51] G. D. Yuan, B. K. G. Theng, G. J. Churchman, and W. P. Gates, "Chapter 5.1. clays and clay minerals for pollution control," in Handbook of Clay Science, Vol. 1 of Developments in Clay Science, pp. 587-644, Elsevier, Oxford, UK, 2013.

[52] W. F. Jaynes and S. A. Boyd, "Clay mineral type and organic compound sorption by hexadecyltrimethlyammonium-exchanged clays," Soil Science Society of America Journal, vol. 55, no. 1, pp. 43-48, 1991.

[53] H. He, R. L. Frost, T. Bostrom et al., "Changes in the morphology of organoclays with $\mathrm{HDTMA}^{+}$surfactant loading," Applied Clay Science, vol. 31, no. 3-4, pp. 262-271, 2006.

[54] Q. Zhao, H. Choo, A. Bhatt, S. E. Burns, and B. Bate, "Review of the fundamental geochemical and physical behaviors of organoclays in barrier applications," Applied Clay Science, vol. 142, pp. 2-20, 2017.

[55] M. Majdan, E. Sabah, M. Bujacka, S. Pikus, and A.-G. Płaska, "Spectral and equillibrium properties of phenol-HDTMAand phenol-BDMHDA-bentonite as a response to the molecular arrangements of surfactant cations," Journal of Molecular Structure, vol. 938, no. 1-3, pp. 29-34, 2009.

[56] P. Djomgoue and D. Njopwouo, "FT-IR spectroscopy applied for surface clays characterization," Journal of Surface 
Engineered Materials and Advanced Technology, vol. 3, no. 4, pp. 275-282, 2013.

[57] B. Fil, C. Özmetin, and M. Korkmaz, "Characterization and electrokinetic properties of montmorillonite," Bulgarian Chemical Communications, vol. 46, no. 2, pp. 258-263, 2014.

[58] S. Akyüz, T. Akyüz, and A. E. Yakar, "FT-IR spectroscopic investigation of adsorption of 3-aminopyridine on sepiolite and montmorillonite from Anatolia," Journal of Molecular Structure, vol. 565-566, pp. 487-491, 2001.

[59] G. Borchardt, "Montmorillonite and other smectite minerals," in Minerals in Soil Environments, pp. 293-330, Soil Science Society of America, Madison, WI, USA, 1977.

[60] H. Patel, R. Somani, H. Bajaj, and R. Jasra, "Preparation and characterization of phosphonium montmorillonite with enhanced thermal stability," Applied Clay Science, vol. 35, no. 3-4, pp. 194-200, 2007.

[61] S. X. Zha, Y. Zhou, X. Jin, and Z. Chen, "The removal of amoxicillin from wastewater using organobentonite," Journal of Environmental Management, vol. 129, pp. 569-576, 2013.

[62] G. A. Ikhtiyarova, A. S. Özcan, Ö. Gök, and A. Özcan, "Characterization of natural- and organobentonite by XRD, SEM, FT-IR and thermal analysis techniques and its adsorption behaviour in aqueous solutions," Clay Minerals, vol. 47, no. 1, pp. 31-44, 2018.

[63] M. Thommes, K. Kaneko, A. V. Neimark et al., "Physisorption of gases, with special reference to the evaluation of surface area and pore size distribution (IUPAC technical report)," Pure and Applied Chemistry, vol. 87, no. 9-10, pp. 1051-1069, 2015.

[64] H. Koyuncu, N. Yıldız, U. Salgın, F. Köroğlu, and A. Çalımlı, "Adsorption of o-, m- and p-nitrophenols onto organically modified bentonites," Journal of Hazardous Materials, vol. 185, no. 2-3, pp. 1332-1339, 2011.

[65] A. Jacobo-Azuara, R. Leyva-Ramos, E. Padilla-Ortega, R. M. Aragón-Piña, R. M. Guerrero-Coronado, and J. Mendoza-Barron, "Removal of toxic pollutants from aqueous solutions by adsorption onto an organobentonite," Adsorption Science and Technology, vol. 24, no. 8, pp. 687-699, 2006.

[66] A. Gładysz-Płaska, M. Majdan, S. Pikus, and D. Sternik, "Simultaneous adsorption of chromium(VI) and phenol on natural red clay modified by HDTMA," Chemical Engineering Journal, vol. 179, pp. 140-150, 2012.

[67] S. Sahnoun and M. Boutahala, "Adsorption removal of tartrazine by chitosan/polyaniline composite: kinetics and equilibrium studies," International Journal of Biological Macromolecules, vol. 114, pp. 1345-1353, 2018.

[68] Z.-X. Han, Z. Zhu, D.-D. Wu, J. Wu, and Y.-R. Liu, "Adsorption kinetics and thermodynamics of acid blue 25 and methylene blue dye solutions on natural sepiolite," Synthesis and Reactivity in Inorganic, Metal-Organic, and Nano-Metal Chemistry, vol. 44, no. 1, pp. 140-147, 2014.

[69] F. Tümsek and Ö. Avc1, "Investigation of kinetics and isotherm models for the acid orange 95 adsorption from aqueous solution onto natural minerals," Journal of Chemical \& Engineering Data, vol. 58, no. 3, pp. 551-559, 2013.

[70] M. K. Satapathy and P. Das, "Optimization of crystal violet dye removal using novel soil-silver nanocomposite as nanoadsorbent using response surface methodology," Journal of Environmental Chemical Engineering, vol. 2, no. 1, pp. 708-714, 2014.

[71] R. K. Gautam, S. Banerjee, M. A. Sanroman, and M. C. Chattopadhyaya, "Synthesis of copper coordinated dithiooxamide metal organic framework and its performance assessment in the adsorptive removal of tartrazine from water," Journal of Environmental Chemical Engineering, vol. 5, no. 1, pp. 328-340, 2017.

[72] A. H. Jawad, R. A. Rashid, M. A. M. Ishak, and L. D. Wilson, "Adsorption of methylene blue onto activated carbon developed from biomass waste by $\mathrm{H}_{2} \mathrm{SO}_{4}$ activation: kinetic, equilibrium and thermodynamic studies," Desalination and Water Treatment, vol. 57, no. 52, pp. 25194-25206, 2016.

[73] H. Ait Ahsaine, M. Zbair, Z. Anfar et al., "Cationic dyes adsorption onto high surface area "almond shell" activated carbon: kinetics, equilibrium isotherms and surface statistical modeling," Materials Today Chemistry, vol. 8, pp. 121-132, 2018.

[74] S. Karimifard and M. R. Alavi Moghaddam, "Application of response surface methodology in physicochemical removal of dyes from wastewater: a critical review," Science of the Total Environment, vol. 640-641, pp. 772-797, 2018.

[75] M. Amini, H. Younesi, N. Bahramifar et al., "Application of response surface methodology for optimization of lead biosorption in an aqueous solution by Aspergillus niger," Journal of Hazardous Materials, vol. 154, no. 1-3, pp. 694-702, 2008.

[76] R. Ansari, M. Banimahd Keivani, and A. Fallah Delavar, "Application of polyaniline nanolayer composite for removal of tartrazine dye from aqueous solutions," Journal of Polymer Research, vol. 18, no. 6, pp. 1931-1939, 2011.

[77] S. Banerjee and M. C. Chattopadhyaya, "Adsorption characteristics for the removal of a toxic dye, tartrazine from aqueous solutions by a low cost agricultural by-product," Arabian Journal of Chemistry, vol. 10, pp. S1629-S1638, 2017.

[78] G. L. Dotto, M. L. G. Vieira, and L. A. A. Pinto, "Kinetics and mechanism of tartrazine adsorption onto chitin and chitosan," Industrial \& Engineering Chemistry Research, vol. 51, no. 19 , pp. $6862-6868,2012$.

[79] J. Goscianska and R. Pietrzak, "Removal of tartrazine from aqueous solution by carbon nanotubes decorated with silver nanoparticles," Catalysis Today, vol. 249, pp. 259-264, 2015.

[80] A. Mittal, L. Kurup, and J. Mittal, "Freundlich and Langmuir adsorption isotherms and kinetics for the removal of tartrazine from aqueous solutions using hen feathers," Journal of Hazardous Materials, vol. 146, no. 1-2, pp. 243-248, 2007.

[81] M. O. Dawodu and K. G. Akpomie, "Evaluating the potential of a Nigerian soil as an adsorbent for tartrazine dye: isotherm, kinetic and thermodynamic studies," Alexandria Engineering Journal, vol. 55, no. 4, pp. 3211-3218, 2016.

[82] W. S. Wan Ngah, N. F. M. Ariff, and M. A. K. M. Hanafiah, "Preparation, characterization, and environmental application of crosslinked chitosan-coated bentonite for tartrazine adsorption from aqueous solutions," Water, Air, and Soil Pollution, vol. 206, no. 1-4, pp. 225-236, 2010. 

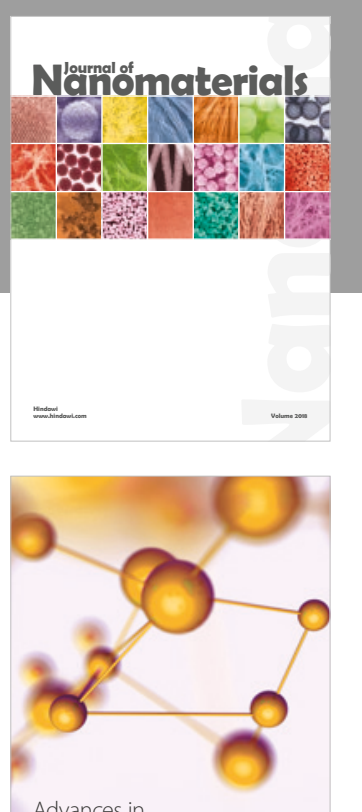

Physical Chemistry
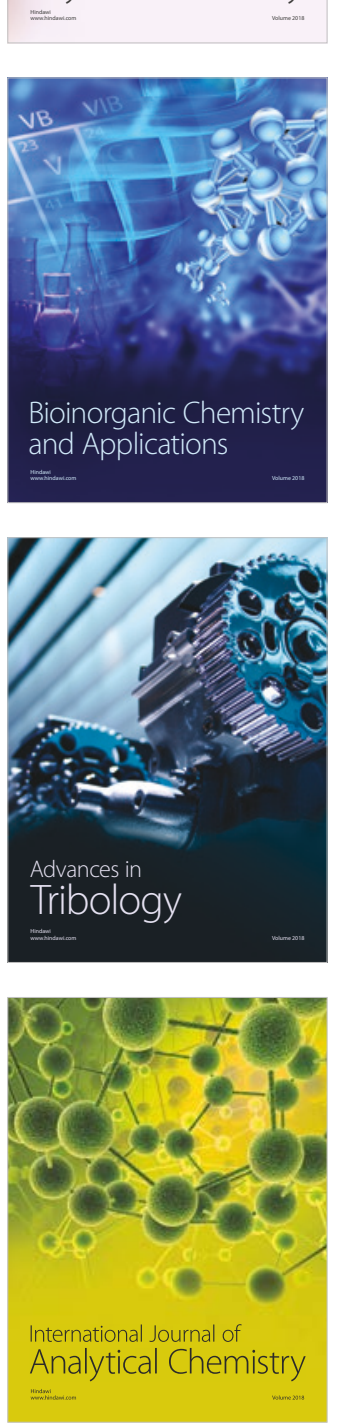

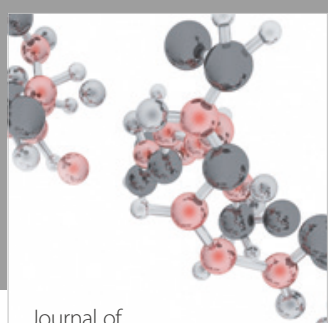

Analytical Methods

in Chemistry

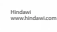

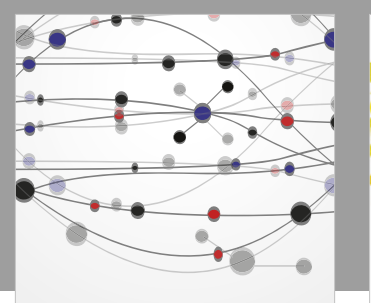

The Scientific World Journal

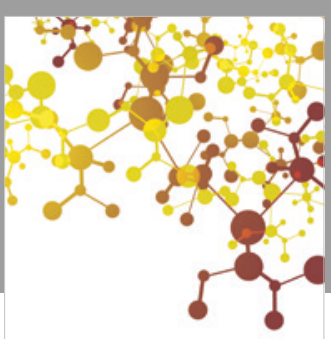

Journal of

Applied Chemistry
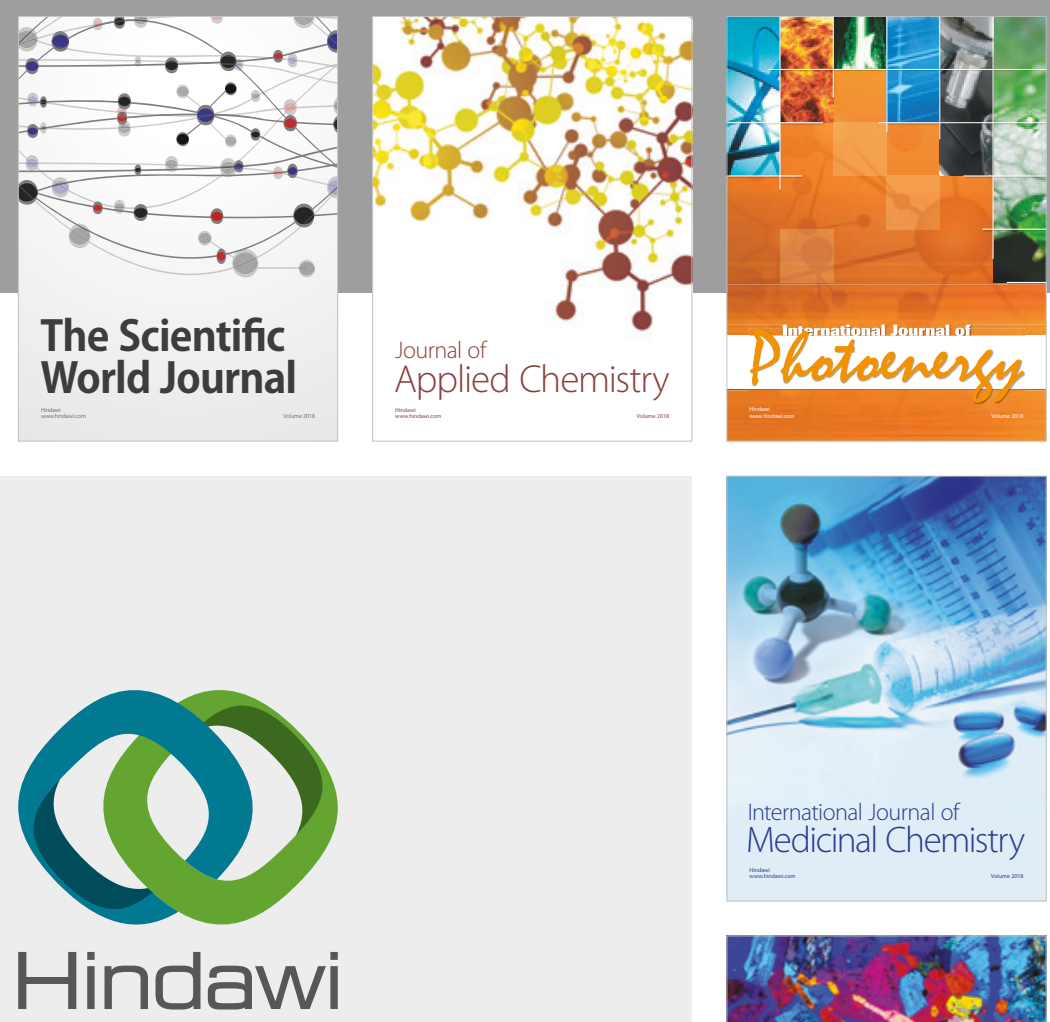

Submit your manuscripts at

www.hindawi.com
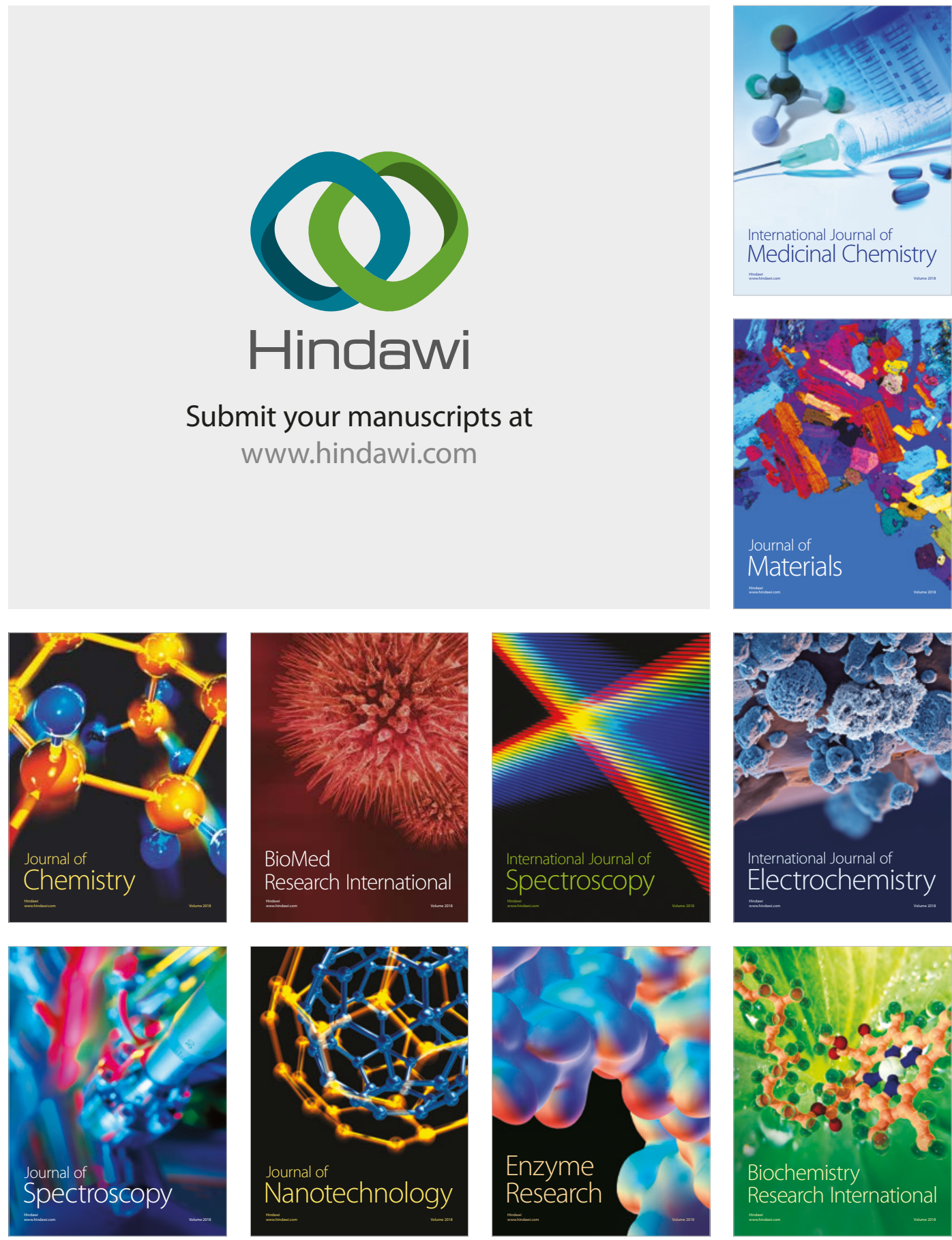
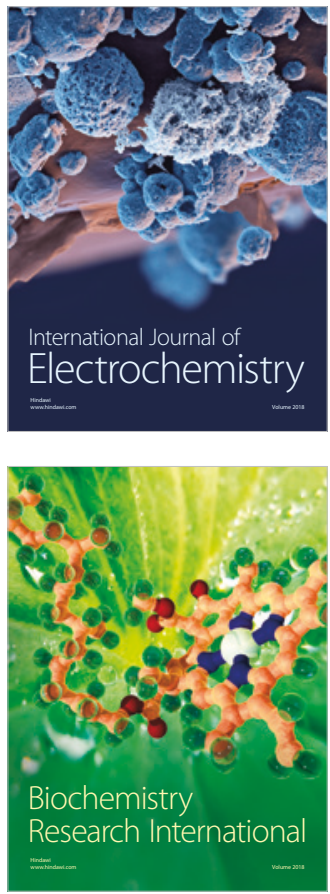